\title{
Imagens de quem escreve: entrenotas sobre o lugar do escritor
}

\author{
Images of who writes: notes about the place of the writer
}

Mestre em Educação também pela Universidade Federal de Minas Gerais (UFMG). Doutorando em Estudos Literários, com ênfase em Literatura Brasileira, pelo Programa de Pós-Graduação em Letras: Estudos
Literários (Pós-Lit), da UFMG. Técnico em Assuntos Literários (Pós-Lit), da UFMG. Técnico em Assuntos
Educacionais no Instituto Federal de Educação Educacionais no Instituto Federal de Educação,
Ciência e Tecnologia do Ceará (IFCE), onde também atua e Te Professor da Pós-gradução na área de Docência na Educação Profissional e Tecnológica. http:///orcid.org/0000-0001-5410-9317

E-mail: andre.letraslp@gmail.com

Recebido em: 11/3/2019

Aprovado em: 20/7/2019.

Endereço para correspondência

Av. Antônio Carlos, 6627, Pampulha, Belo Horizonte,

MG, CEP: 31270-901
André Magri Ribeiro de Melo ${ }^{1}$

Universidade Federal de Minas Gerais, Faculdade de Letras, Programa de Pós-Graduação em Letras: Estudos Literários, Belo Horizonte, MG, Brasil.

\section{RESUMO}

O diálogo entre diferentes artes é uma das marcas da teoria e da crítica literária e cultural contemporâneas, interessadas no caráter interdisciplinar dos fenômenos culturais e objetos artísticos. Nesse ensaio, analiso alguns aspectos da relação entre imagem e palavra na obra fotobiográfica $O$ lugar do escritor, do fotógrafo Eder Chiodetto. A partir da leitura de algumas fotos e comentários dos escritores, proponho conexões entre as noções de punctum e biografema, nos termos de Roland Barthes, que operam em estreita relação com a dissolução de fronteiras rígidas na estética contemporânea, quer seja no âmbito da crítica biográfica ou iconográfica. Concluo a discussão realçando a impureza e a efemeridade como aspectos basilares do trabalho de Chiodetto, cuja originalidade e beleza estão apartadas da linearidade, do sequenciamento ortodoxo e da consecução objetiva. A morte - captada pelo flash da câmera - e a vida - reinventada em fragmentos de si entregues pelos escritores - estão implicadas uma na outra, duplamente contaminadas. Palavras-chave: Fotografia. Literatura. Crítica biográfica. Crítica iconográfica. Literatura brasileira.

\section{ABSTRACT}

The dialogue between different arts is one of the marks of contemporary literary and cultural theory and criticism, interested in the interdisciplinary character of cultural phenomena and artistic objects. In this essay, I analyze some aspects of the relationship between image and word in the photobiographical work The place of the writer, by photographer Eder Chiodetto. From the reading of some photos and commentaries of the writers, I propose connections between the notions of punctum and biographeme, in the terms of Roland Barthes, that operate in close relation with the dissolution of rigid borders in contemporary aesthetics, whether in the scope of biographical criticism or iconographical. I conclude the discussion by highlighting impurity and ephemerality as the basic aspects of Chiodetto's work, whose originality and beauty are separated from linearity, orthodox sequencing and objective attainment. Death - captured by camera flash - and life - reinvented in fragments of itself delivered by writers - are implicated in each other, doubly contaminated.

Keywords: Photography. Literature. Biographical criticism. Iconographical criticismo. Brazilian literature. 
"Nada, se quisermos examinar bem a coisa, é indiferente num retrato. O gesto, a expressão, a indumentária, o próprio cenário, tudo deve contribuir para representar um caráter [...]. Enfim, seja qual for o meio mais visivelmente adotado pelo artista, seja ele Holbein, David, Velásquez ou Laurence, um bom retrato sempre me parece uma biografia dramatizada, ou melhor, como o drama natural inerente a qualquer homem".

(Charles Baudelaire)

\section{0 escritor: fulguração imagético-biográfica}

entelhas a céu aberto. Luz que vagueia entre apagar e acender. Um mundo-imagem vertido em detalhes esparsos. A vida em dobras, avessa às linhas, inscrita na ordem do instante, da contingência e da diferença. 0 passado e o futuro diluídos no presente. 0 escritor é alçado à condição de luz em curto-circuito que se projeta a partir da escuridão, do movimento e da descontinuidade: um vagalume. Seu lugar, o tempo-espaço da ficção, da criação, do trabalho de escrita, oscila em meio às faces disformes de si e da sua obra: sucedido desgovernado, relembrando as palavras de Rosa em seu romance-sertão. Ora, se Baudelaire nos convida a pensar em uma biografia dramatizada tomando como cerne dessa metáfora o retrato, Norbert Elias, em A sociedade dos indivíduos, dirá que o rosto - mais que qualquer outra parte do corpo - é a "vitrine da pessoa". Ainda que o poeta e o historiador não se ocupem diretamente da relação entre fotografia e biografia, relato e imagem, suas provocações iluminam excertos do que se tratará aqui.

As diferentes modalidades de artes, inclusive no campo das estruturas técnicas e estéticas, são objeto de estudo frequente na crítica literária e cultural contemporânea. Cisões rígidas no passado, embora ainda localizáveis - em alguma medida - no presente, já não gozam do mesmo espaço e prestígio anteriores, principalmente porque as condições histórico-culturais que catapultaram noções como as de "belas artes" ou "artes aplicadas" à ascensão já não encontram ecos tão propagáveis em nosso tempo histórico. Estruturas que têm como escopo a departamentalização das artes estão na contramão das dinâmicas socioculturais vigentes, cujo aspecto central é a intercalação hibridizada manifesta na vasta cadeia de textos intermidiais que integram, com acentuada intensidade, os fenômenos políticos, sociais, estéticos e econômicos dessas primeiras décadas do século XXI.

Os estudos de paralelismos, analogias, semelhanças e dissensos entre as artes culminou no surgimento da Literatura Comparada como disciplina interessada, antiteticamente, na crítica à disciplinaridade ortodoxa e ao estatuto ora puro, ora sagrado do texto literário. Pautado pela contaminação intra/intertextual, o comparativismo na teoria literária voltou-se para tradições não ocidentais, obras marginalizadas pelos sistemas literários vigentes e experiências de trocas estético-culturais entre diferentes nações, comunidades e sujeitos com suas múltiplas práticas artísticas e percepções de mundo.

0 contato e a contaminação entre a literatura e a fotografia respondem, assim, às diferentes mutabilidades insurgentes no campo artístico-cultural comparativista, embora essa relação não seja recente, mas localizada na história da arte já em tempos remotos, como é o caso dos hieróglifos egípcios, da poesia epigramática ou da écfrasis - todas práticas artísticas que desde a Antiguidade constituíam territórios interdisciplinares da produção humana a partir da conjugação entre elementos plurilinguísticos e diversas manipulações iconográficas que mimetizavam o cotidiano e a imaginação (FLUSSER, 1986). Nesse sentido, é sobre a clivagem entre palavra, imagem e figurações autobiográficas que me ocuparei nesse texto.

\section{Chiodetto e a foto-narrativa}

Entre os anos de 1997 e 2002, o fotógrafo paulistano Eder Chiodetto visitou vários escritores brasileiros buscando acessar as suas chaves para o mundo da ficção, como conta no prefácio do livro O lugar do escritor, publicado pela Cosac Naify, que é uma composição de fragmentos biográficos e fotos desses autores, seus escritórios, manuscritos, objetos, bibliotecas e outras ambiências literárias e arquivísticas. Com mais de 70 exposições realizadas na última década, no Brasil e em outros países, Chiodetto tem atuado especialmente no campo da curadoria fotográfica. Além da famosa fotobiografia literária premiada com o Jabuti na categoria "Arquitetura, Urbanismo, Fotografia, 
Comunicação e Artes", em 2004, publicou obras relevantes para a consolidação e diversificação dos estudos da imagem, como Geração oo: A Nova Fotografia Brasileira (Edições Sesc) e Curadoria em Fotografia: da pesquisa à exposição (Ateliê Fotô/Funarte). Em conexão com seu papel como curador e crítico de fotografia, ele também tem se dedicado à organização e edição de livros que reúnem a produção de importantes fotógrafos, a exemplo de Luiz Braga, German Lorca, Cristiano Mascaro, Araquém Alcântara e Ana Nitzan.

Zonas imprecisas em torno do fazer literário parecem orientar o trabalho fotobiográfico de Chiodetto, especialmente no livro que é objeto destas reflexões, tanto do ponto de vista da concepção artística quanto das figurações epistêmicas ali sugeridas. 0 escritor é tomado como invenção e o seu lugar é uma arquitetura de mundos ilimitados capazes de ampliar as fronteiras do imaginário. Domínios do artifício e da representação, vida e ficção conjugam o fragmento em sua inteireza e condensação, à maneira das bonecas russas Matryoshkas (матрёшка), reivindicando a presença fracionada do corpo que escreve no próprio texto e, paralelamente, o estatuto da fotografia enquanto simulacro do sujeito, ambas metaficcionalizando a vida como objeto da arte (BERNARDO, 2010).

Ficcionalizar o real para pensá-lo é uma condição incontornável do trabalho crítico de ler as relações entre literatura e fotografia na contemporaneidade, em especial no âmbito da crítica biográfica e da iconografia, que dialogam com a impossibilidade de apreender uma realidade, como o passado narrado ou uma pessoa fotografada. Em ambas as situações, estamos diante de representações que cotejam elementos específicos de uma estrutura inacessível por completo. Só tocamos os traços deixados para trás, que guardam possibilidades de movimento a partir dos espectros de infinitas interpretações. Os vagalumes não se obrigam a revelar a escuridão, mas iluminam contornos, formas e ampliam o horizonte de percepções do olho que vê sabendo que é preciso imaginar para compor cenas e grafias.

\section{Rastros de si: entre lampejos e palavras}

A foto reproduzida na Imagem 1 traz o mineiro Autran Dourado (1926-2012). 0 escritor é um borrão, uma centelha em deslocamento, casca e caco de uma vida em meio às vidas de papel que são o fundo da sua passagem. Ele é o punctum, no sentido barthesiano: fragmento de imagem que me comove, me fere e me inquieta por escapar à possível intenção da lente e do fotógrafo de captar algo claro e delineado, por escapar dos grilhões do meu entendimento apriorístico. Em uma paradoxal imobilidade viva, o escritor vagalume aprisionado na foto é o detalhe que povoa minha leitura, uma transmutação viva do meu interesse, fulguração, estalo, travessia do vazio, uma marca que torna a foto em "alguma coisa", não mais qualquer coisa.

Imagem 1 - Autran Dourado

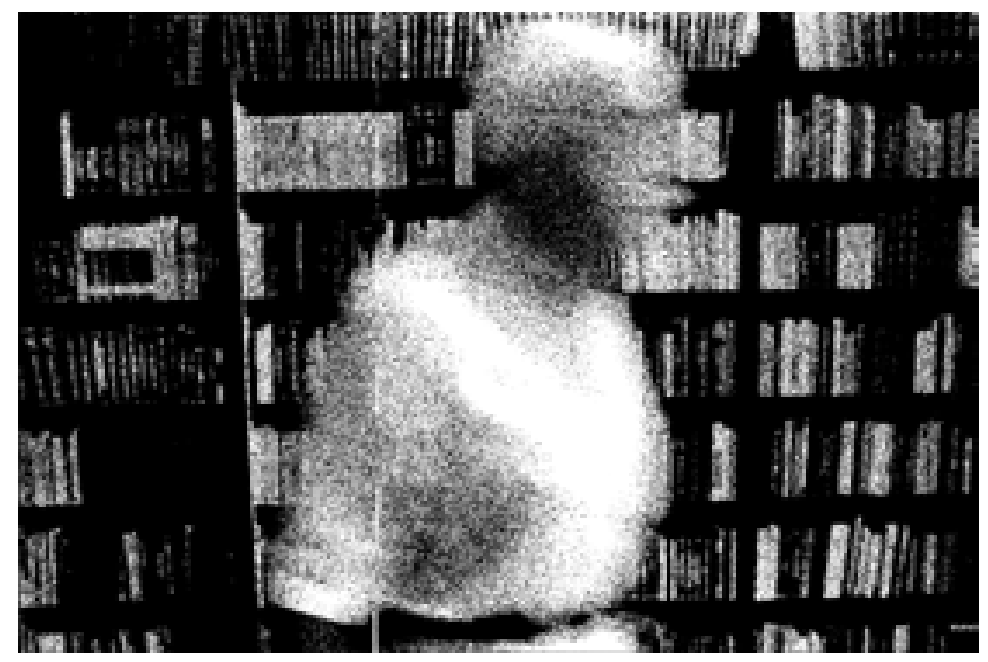

Fonte: Eder Chiodetto, 2002, p. 132.

0 traço do escritor remete a esses resquícios capturados pela câmera, à força de expansão e de expressão daquele que escreve, metáfora iconográfica do retorno crítico do autor à literatura e à filosofia como um vulto de si mesmo, ruínas do cogito ergo sum. A sua condição residual, desenhada em rastros de assinatura e contra-assinatura, está na contramão de antigos procedimentos psicologizantes que relacionavam assepticamente recalque e pacto ficcional com a escrita. 0 punctum é um fragmento inteiriço, como o espectro de Autran mortificado por Chiodetto. Em um paradoxo metonímico, o corpo disforme em mobilidade é uma minúcia, um ponto partícipe da cena, que também preenche toda a fotografia. 
O lugar do escritor sugerido na foto é o lugar do lapso, do trânsito e da mudança - à semelhança da canção "As vitrines", de Chico Buarque, que infere as imagens da visão embaraçada e brincante, das sombras que se multiplicam e da poesia que entorna do chão. A figura do flâneur benjaminiano, símbolo errante da modernidade cuja itinerância pela cidade inspira sua atenção ao nascer dos acontecimentos, também contém estreita relação com a tematização do sujeito/personagem escritor e seu lócus de criação e trabalho. Seja na literatura ou na fotografia, nossos tempos movediços e cindidos pelo nomadismo que esfarela identidades fixas e projeta artistas e obras de arte em devir acenam para a impossibilidade latente de compartimentar as diferentes linguagens artísticas em virtude da sua condição pós-disciplinar.

Caminhante, são teus passos

o caminho e nada mais;

Caminhante, não há caminho,

faz-se caminho ao andar².

$[\ldots]$

Os versos do modernista espanhol António Machado evocam a caminhada como referente do caminho e catalisam o sentido alegórico da foto de Autran Dourado para o espaço da crítica biográfica contemporânea, cujo desenho teórico-crítico orquestra-se de modo rapsódico nas dobras do (im)possível, metaforizando o real e ficcionalizando a história sem, contudo, incorrer em distorção das verdades factuais ou proposição de engodos. A desestabilização dos sentidos e abertura do coração ao acaso, como o golpe de dados de Mallarmé, é um marco na produção fotobiográfica de Chiodetto, que age conforme o bricoleur de Lévi-Strauss entremeando fragmentos imagéticos e estilhaços biográficos com as linhas abissais da luz em colapso que emana dos pirilampos.

Do original: Caminante, son tus huellas, el caminho y nada más; caminante, no hay caminho, se hace caminho al andar (tradução nossa).
Imagem 2 - Ana Miranda

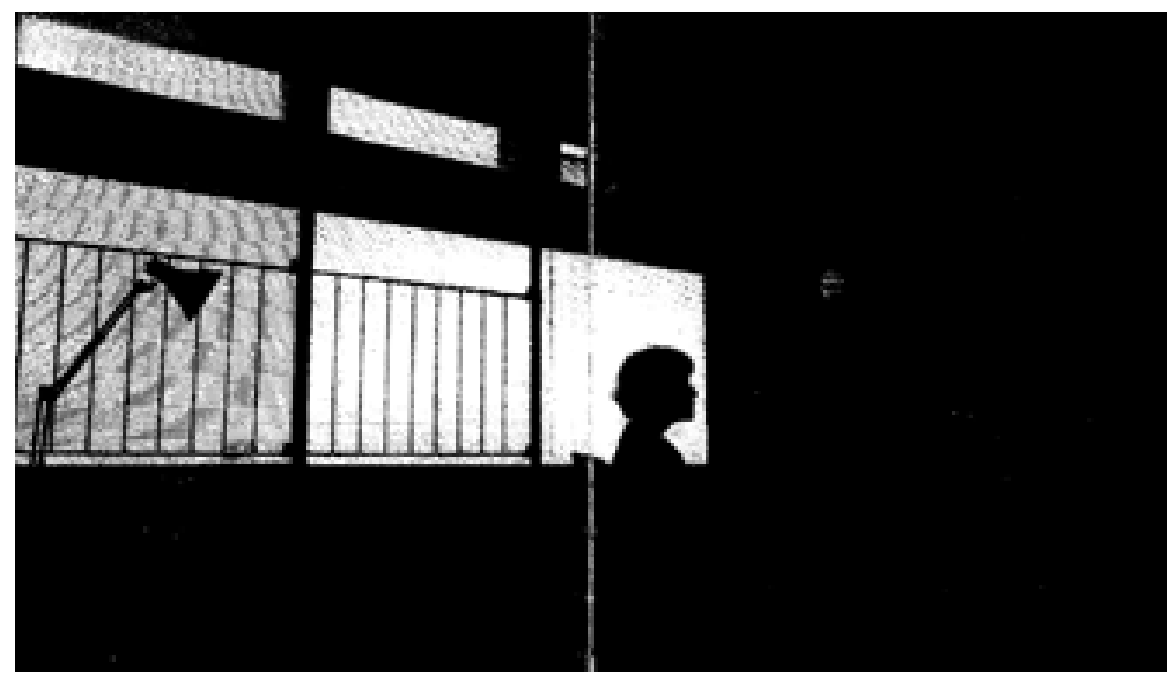

Fonte: Eder Chiodetto, 2002, p. 144.

Jogo de claridade e escuridão. Encontro entre formas iluminadas e territórios sombrios. Diluição do corpo nas câmaras de luz e sombra. A fotografia da cearense Ana Miranda expõe o que Jacques Derrida chamou de enxerto: a incisão, o discurso como inseminação, a dupla tradução, a contaminação de dois ou mais textos que se transformam e se deformam um pelo outro, sem que possamos diferenciá-los ou ceifá-los com traços próprios, pois se tornaram aporia do indecidível e território de ambivalências. A foto (Imagem 2) revela, portanto, a mutação intertextual entre a escritora e o escritório, espaços da fabulação de si. São palavras de Ana Miranda: "o escritório é a extensão do meu corpo. Circulo por ele como se estivesse dentro da minha mente. É lugar de isolamento, mas de nenhuma, nenhuma solidão" (MIRANDA apud CHIODETTO, 2002, p. 143).

$\mathrm{O}$ fragmento biográfico narrado pela escritora pode ser lido como um "biografema"3, noção cunhada por Roland Barthes que ultrapassa o paradigma

Neste trecho do prefácio de Sade, Fourier, Loyola, Roland Barthes discorre sobre a noção de biografema: "Se eu fosse escritor, já morto, como gostaria que a minha vida se reduzisse, pelos cuidados de um biógrafo amigo e desenvolto, a alguns pormenores, a alguns gostos, a algumas inflexões, digamos: 'biografemas', cuja distinção 
biográfico clássico da escrita de uma vida e se ocupa de palavras, pontuações, traços, rastros, letras, imagens e outros artefatos artísticos e linguísticos. Partindo de uma inspiração lacaniana, é possível pensar o biografema análogo ao inconsciente e em contraponto com o duplo biografia/consciente. Em função da relação singular que o conceito inaugura no tratamento das linhas de contato entre vida e obra, refaz os lugares do escritor diacrônica e sincronicamente e adere não mais à totalidade de uma história, mas à captura de puncta, em um ato similar ao clique desavisado da câmera fotográfica. Essa é a posição de Chiodetto quando se furta a relatos biográficos consecutivos e lineares sobre os escritores em seu livro e prioriza vestígios e detalhes que iluminam o escopo da sua composição fotobiográfica: o lugar do escritor e sua articulação pontilhada com o trabalho artístico da escrita.

No caso de Ana Miranda, a demanda por isolamento para a criação literária é um imperativo diretamente agregado ao escritório, um lugar de acentuada importância para ela e que, na leitura iconográfica do fotógrafo, se funde ao corpo dela ratificando suas próprias palavras quando descreveu aquele espaço como uma extensão de si mesma, tanto física quanto psicológica. "Nesse espaço, encontro portas" (MIRANDA apud CHIODETTO, idem). É o que a escritora diz em outro biografema, em um adensamento das quatro paredes que a cercam enquanto constrói sua alma, "uma maneira de ser, uma forma de ver o mundo" (MIRANDA, apud CHIODETTO, idem). Os efeitos fotocromáticos que resultaram na penetração entre duas realidades - a escritora e o seu lugar criam uma atmosfera instável que dissolve fronteiras, uma característica que se estende à obra histórico-ficcional da romancista, notadamente atravessada pelos dilemas, contradições, potencialidades e ambiguidades da relação entre história e literatura, ficção e realidade, invenção e memória.

Assim como há traços em uma fotografia que nos encantam mais que outros e nos expulsam da própria foto porque nos ferem e nos expõem a algo desconhecido em nós mesmos, desmontando as intenções do fotógrafo e da própria imagem - punctum -, uma biografia também traz consigo trechos que estilhaçam nosso modo de tocar e ler uma vida - "biografema". Desafeitos ao universalismo, esses elementos respondem a contextos pessoais e a motivações

e mobilidade poderiam viajar fora de qualquer destino e vir tocar, à maneira dos átomos epicurianos, algum corpo futuro, prometido a mesma dispersão; uma vida esburacada, em suma, como [...] um filme a moda antiga, de que está ausente toda palavra e cuja vaga de imagens [ ] e entrecortada, a moda de solucos salutares, pelo negro apenas escrito no intertítulo, pela irrupção desenvolta de outro significante" (BARTHES, 2005, p. XVII).

Letrônica | Porto Alegre, v. 12, n. 3, jul.-set 2019: e33500 íntimas em cada leitor, fotógrafo ou escritor, pois os saberes literários e iconográficos, a exemplo dos demais, são construídos a partir de perspectivas.

Afinal, quem olha uma fotografia e é atingido por um punctum ou quem se depara com uma história de vida e é pinçado por biografemas que estilhaçam uma imagem unívoca "[...] olha de um determinado ângulo, com o propósito deliberado de apreciar, de dizer sim ou não, de seguir todos os traços do veneno, de encontrar o melhor antídoto". Ou seja, não podemos impor ao que olhamos o falseamento aniquilador, considerando que o olhar sabe tanto de onde olha quanto o que olha (FOUCAULT, 1986, p. 30).

Imagem 3 - Régis Bonvicino

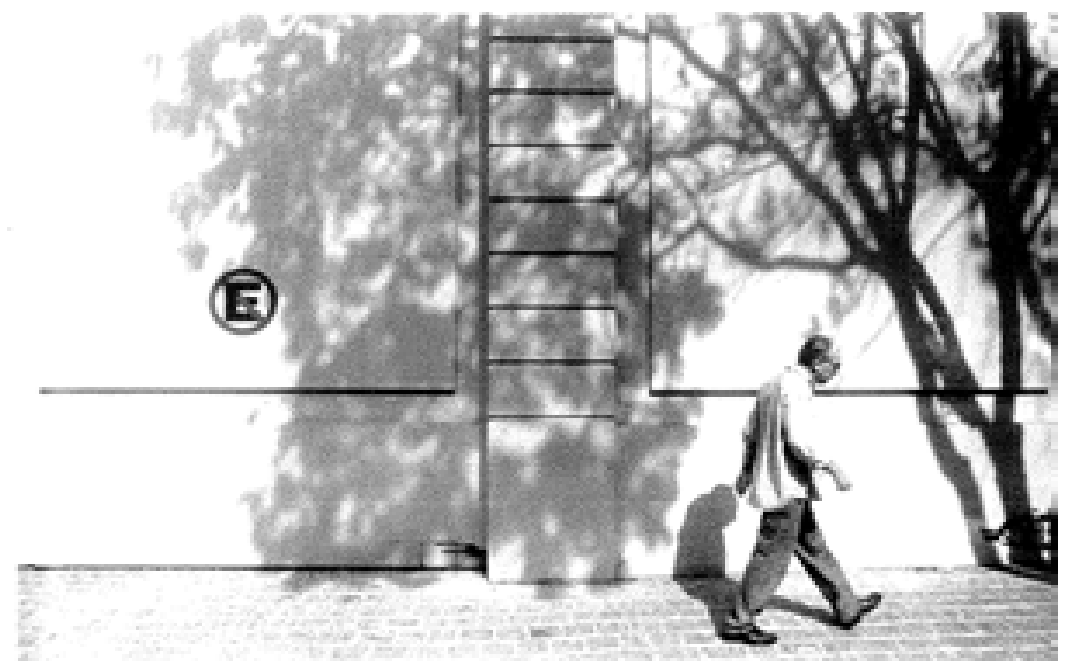

Fonte: Eder Chiodetto, 2002, p. 53

Poeta paulistano, Régis Bonvicino compara o ofício de escritor ao de músico de jazz (Imagem 3). Nos dois casos, o advento da improvisação é relevante. Na opinião do autor, o fato do músico de jazz chegar a qualquer lugar e produzir música se configura em uma espécie de sintaxe do caos, estilo de composição artístico-literária que alega estar muito presente nele. Caos e improviso são as energias que impulsionam a poética de Bonvicino intercalando-a à música. $\mathrm{A}$ 
relação entre diferentes domínios artísticos culmina em um território propenso à emergência da poesia, do literário, alinhavando partitura e escritura em uma montagem que articula pensamento e emoção.

0 verso de Fernando Pessoa "o que em mim sente está pensando" (PESSOA, 2005, p. 111) e a proposição Deleuze-Guatarriana de que teorizar é pensar (DELEUZE; GUATARRI, 1992) ilustram o processo de escrita do poeta-músico. Outro elemento que merece destaque é a ligação entre o músico de jazz que produz a céu aberto e o lugar que Bonvicino arroga para si na condição de escritor. Seus biografemas deixam entrever que o isolamento não lhe agrada e, tampouco, a ideia de escrever recluso em um gabinete. Seu lugar é o não lugar, esboçado no descentramento do escritório, na ambivalência da solidão e da relação com o exterior: "a experiência de andar na rua sempre me foi estimulante" (BONVICINO apud CHIODETTO, 2002, p. 52).

Capturado em movimento por uma rua próxima à sua casa, o espectro do escritor na foto inscreve-o como caminhante à procura de algo, ilação que arrisco a partir de sua autonarração biografemática: "alguém me manda um e-mail, acho que tem alguma coisa legal, junto com alguma frase que ouvi na rua" (BONVICINO apud CHIODETTO, 2002, p. 52). Essa postura diante da vida e do ofício de escrever assemelha-se ao modus operandi do chiffonier tematizado por Walter Benjamin (1989) em alusão à poesia moderna de Baudelaire.

Se o chiffonier busca os restos, os trapos, aquilo que o consumismo exacerbado caro à modernidade acumula nas ruas ou mesmo os fragmentos memorialísticos à deriva que a história oficial descarta por não saber o que fazer (ou não querer fazer nada) com eles, Régis Bonvicino parece adotar um posicionamento similar quando desmistifica o isolamento da escrita e dessacraliza o espaço do gabinete. Nesse caso, a convivência com a rua e seus personagens e a aparente banalidade de um e-mail ou de uma frase dita a esmo em uma praça podem vir à tona como as sobras ressignificadas de um mundo que, supostamente, não interessaria ao escritor encerrado na clausura da sua egoica torre de marfim.

Em Sobre a fotografia, Susan Sontag evoca a figura do trapeiro baudelairiano ao lembrar que ele cataloga e recolhe "tudo o que a cidade jogou fora, tudo o que perdeu, tudo o que desprezou, tudo o que esmagou a seus pés". Essa busca, no entanto, embora algo errática, não é pautada por uma "seleção sábia", levada a cabo por alguém que, com avareza, "recolhe o refugo que vai assumir a forma de objetos úteis ou gratificantes entre os dentes da deusa da Indústria" (SONTAG, 2004, p. 93).

A placa que proíbe estacionamentos é o traço que me provoca na leitura da fotografia. A simbologia da proibição e a subversão que a poesia e o poeta imputam ao mundo toma forma nas sombras que a copa da árvore projeta sobre o caminhante, sobre o caminho e sobre a parede rígida e concreta como a ordem cifrada pelo código de trânsito nacional. A sombra desordenada, lacunar, rasgada e atravessada pelos raios solares que se confundem com a leveza das folhas estaciona onde é proibido. De outro ângulo, porém, a placa é amiga do poeta e da poesia, pois fixa uma regra indispensável à literatura: mantenhase em movimento, não estanque, circule entre os interstícios da vida. A placa informa que o lugar do escritor pode ser qualquer topos, desde que sua palavra caótica se espalhe como os acordes improvisados de um jazz ao fim da tarde.

Imagem 4 - Bernardo Carvalho

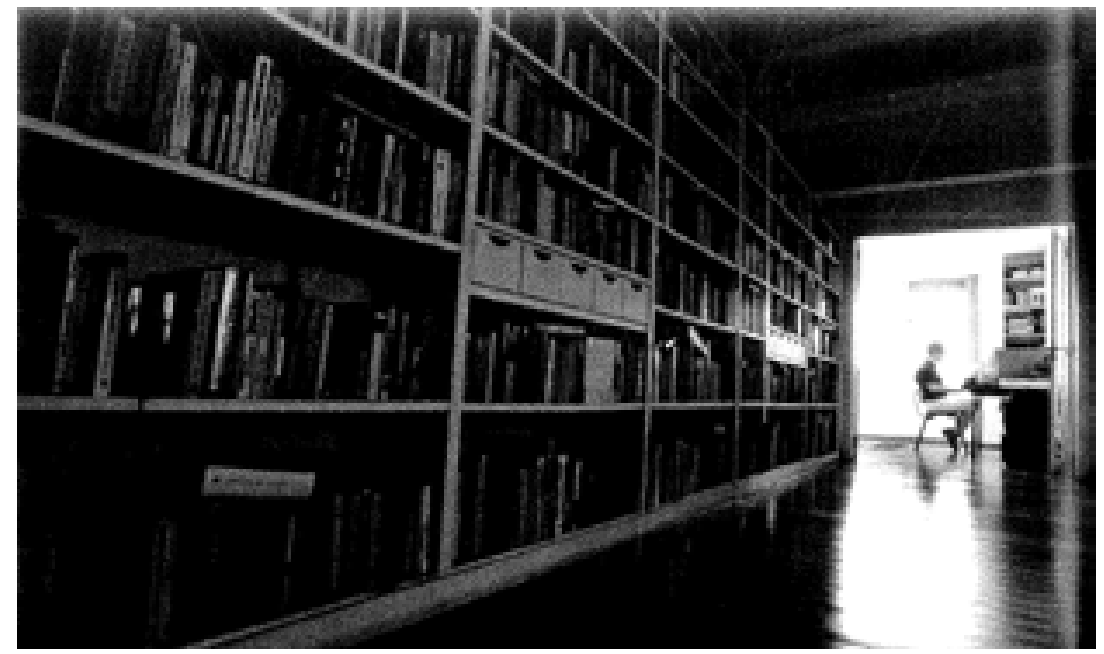

Fonte: Eder Chiodetto, 2002, p. 148.

Na fotografia do carioca Bernardo Carvalho (Imagem 4), salta aos olhos seu tamanho diminuto em relação ao seu escritório, cuja maior parte é tomada 
por uma grande e organizada biblioteca. A lente da câmera captou com singularidade essa representação fantasmagórica do escritor, que luz sozinho à sua mesa no final de um corredor bibliográfico imponente. 0 espaço é um elemento basilar no trabalho de escrita do romancista, que o julga determinante para acessar o mundo imaginário ou, como prefere Chiodetto, as chaves da ficção. Exigência, minúcia e ares de perfeccionismo são componentes marcantes do ritual de organização do escritório, seu legítimo lugar de escritor:

[...] preciso de um lugar tranquilo, sem barulho ou poluição. Arrumo a casa de forma que tenha o maior conforto para poder entrar nesse outro lugar. 0 escritório tem que ser despojado, limpo, neutro e ter ao menos uma frestinha na janela com uma boa vista [...], preciso construir um ambiente, uma espécie de muralha contra as coisas cotidianas (CHIODETTO, 2002, p. 59).

Pontual, objetivo, pragmático e asséptico, o lugar do escritor nos biografemas de Bernardo Carvalho é construído em torno de uma aura que o eleva a uma posição quase sagrada dentro de uma mística doméstica que tenciona a quebra de laços com a realidade e o cotidiano. O lugar do escritor é uma espécie de fortaleza, que o protege das impurezas da vida e dos seres humanos comuns. É um lugar que, a princípio, não é parte da economia da casa convencional, pois o próprio autor precisa criar uma lógica de confortabilidade suficientemente satisfatória para, só então, adentrar "nesse outro lugar". Esses traços ventilam uma leitura iconográfico-biográfica pautada no contraste entre a presença da figura do escritor na foto e as dimensões gulliverianas do gabinete.

Em comparação com o trabalho literário de Carvalho, no qual os desfalques, as incompletudes e a narrativa em curto-circuito tomam fôlego com lampejos e estilhaços esparsamente distribuídos ao longo dos seus romances, a fotografia que o coloca em segundo plano parece convergir com a imagem dos seus próprios personagens: destituídos de poderes, caçando peças de um tempo irrecuperável, às margens de um romance cujo próprio estatuto é questionado formal, sintática e tematicamente. É possível que o seu escritório ocupe o espaço central da sua foto porque a sua figura de escritor ensaia uma condição menor e fragmentária, aspecto que alinhava a sua concepção de sujeito narrativo despojado de racionalidade e de autonomia.
Deparar-se com um quase borrão de escritor ao fim de uma espécie de túnel de papel encena uma limitação da fotografia como objeto artístico e produção histórico-cultural e, consequentemente, dos nossos modos de ler uma imagem. A sensação que se projeta no espectador da foto em relação ao escritor posicionado à sua mesa de trabalho é de inacessibilidade. 0 que está no fundo é inalcançável porque está protegido pelas muralhas intransponíveis do tempo mortificado pela câmera e o mesmo ocorre quanto à fotografia.

Se converterá em equívoco qualquer leitura hermenêutica voltada para a imagem que interrogue o que não está na superfície, aquilo que não é casca ou máscara, posto que tudo na fotografia é simulacro, é estilhaço, luz que lampejou e apagou, frincha do real congelada em um fundo inatingível porque origem e verdade foram rasuradas pelo clique da máquina. São irrecuperáveis as razões e os sentidos por trás de uma fotografia. 0 que resta é a superfície a ser escrutinada, cacos especulares.

A fotografia, como lembra Roland Barthes em A câmara clara (1979), lança recortes sobre a história. Ela é contingente, um produto do impulso artístico da representação. A foto é da ordem das cascas, em uma aproximação com as descrições reflexivas e sensíveis de Georges Didi-Huberman (2017) em seu relato sobre visita que fez aos campos de concentração nazistas Auschwitz e Birkenau. 0 livro diminuto e denso transpassa as fronteiras da descrição e se constitui como uma metodologia que se vale da "casca" como princípio metonímico para ler fotografias e outras imagens. Um procedimento central ao confronto com imagens que povoam nossa existência é tratá-las sem a pretensão de fazer emergir delas tudo que escondem. A leitura iconográfica de fotografias supõe a interrogação das camadas temporais que precisamos atravessar até chegar nelas e, assim, levarmos à frente o exercício bricolar de correlacionar o passado e o agora a partir do nosso próprio presente. 
Imagem 5 - Adélia Prado

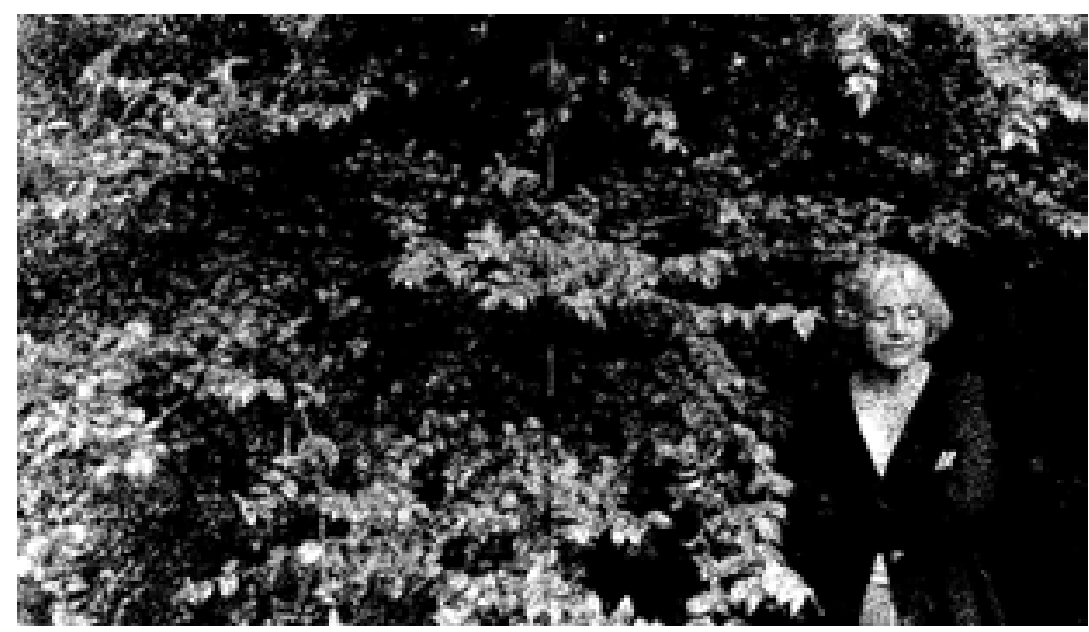

Fonte: Eder Chiodetto, 2002, p. 20.

Cidadã e filha de Deus no mundo. É assim que Adélia Prado, poeta mineira de Divinópolis, refere-se a si em um de seus biografemas, frestas d'uma história de vida que podem passar despercebidas se não lemos com olhos estilhaçados e vagueantes os fragmentos textuais, a escritura no que resguarda de pirilampo, o que pisca descontinuamente e, paradoxalmente, compõe o cenário de uma realidade porvir, não dada, aberta às modulações e intempestividades de quem se confronta com a ficção da experiência vivida e narrada.

Olhos baixos, aura reflexiva, braços cruzados que sugerem a sustentação de si, cabelos embranquecidos pelo tempo, corpo colocado ao lado e dentro da folhagem que toma a maior parte da fotografia (Imagem 5). As folhas se amontoam caoticamente em torno de si e da autora, que repousa solene entre elas. Alheia a inícios ou fins, centros e margens, a foto se configura em um lugar de pensamento rizomático, que se amplia e se alarga, se expande e circula, converge e diverge, compõe e se dissipa, por direções múltiplas.

A multidão de folhas evoca a multiplicidade que cinde a escritora e o seu lugar na imagem. Pensada como rizoma, a foto assume os contornos geográficos de um mapa, em virtude de sua abertura à ilação, à inferência e à especulação, sendo "conectável em todas as suas dimensões, desmontável, reversível, suscetível de receber modificações constantemente" (DELEUZE; GUATARRI, 1995, p. 22). Superfície de simulacros, o recorte do real que congela folhagem e escritora suscita, a contrapelo, a fertilidade do pensamento-criação matizado de mobilidades e transitoriedades. Se vejo um punctum, não poderia ser outro senão a desordem, a não direção, a anarquia frondosa de folhas, galhos e ramagens condensadas no corpo da escritora em pose meditativa, linha com a qual cose sua obra poética de profundo apelo simbólico.

Não é coincidência a forma respeitosa e humilde como Adélia se coloca na fotografia. Deixar-se fotografar é se expor à microexperiência de morrer, é reconhecer na fotografia um inventário da mortalidade: "basta, agora, um toque do dedo para dotar um momento de uma ironia póstuma" (SONTAG, 2004, p. 85). Posicionar-se ao lado da natureza, outro componente de força retumbante em sua obra, resvala a graça do contrassenso entre morrer momentaneamente e, segundos depois, se dispersar, mudar e seguir o curso da própria vida. A contradição se ergue do choque entre o protocolo mortificador da foto e a dinâmica espacial do cenário fotografado, que remete, duplamente, à paralisação e ao fluxo da existência, à morte e ao retorno molecular da escritora, inscrita nos vincos de cada folha.

Sem biblioteca ao fundo, destituída do advento das pilhas de livros comuns a fotografias de escritores e seus lugares de trabalho, a poeta divinopolitana conta: "não separo a mãe e a dona de casa da escritora. Sou uma mulher casada, tenho filhos, casa e escrevo. Tudo junto. Por isso o escritório é a minha vida. Se montasse um escritório, ficaria pateta lá dentro, não teria o que fazer" (PRADO apud CHIODETTO, 2002, p. 22). A atmosfera sacrossanta de um lugar específico para escrever não cabe na cinesia cotidiana e mesmo que Adélia acredite na correspondência entre dom divino e literatura - "é um presente divino que preciso guardar", "se você tem um dom [...]" (PRADO apud CHIODETTO, 2002, p. 22) -, ela não ignora que é preciso cuidar da escrita "como um operário", arrematando o escrever como trabalho e rejeitando o artifício do isolamento.

"A vida está pulsando ali", diz ela sobre o dia a dia. E prossegue: "vejo criação literária e vida pessoal como um tecido único. Não separo. O livro faz parte da casa, da comida, da experiência, da maternidade, do cotidiano. Também não separo a experiência religiosa da experiência poética" (PRADO apud CHIODETTO, 2002, p. 22). 0 laço indissociável entre os diferentes perfis identitários da poeta e seus poemas ratifica o pressuposto da desestabilização do referencial na narrativa 
pós-holocausto e, com ênfase, na literatura brasileira contemporânea, na qual o princípio enunciativo e performático do "mentir-verdadeiramente", ligado ao teatro, tem ocupado centralidade como dispositivo de invenção e estetização da memória que coloca nas mãos do sujeito o gesto de dessubjetivação que o encetará nas dinâmicas do jogo fabular da narrativa e da poética. A fala de Adélia coaduna-se com a complexa trama de efeitos discursivos que demanda a ausência/ presença do escritor na fissurada cena enunciativa, que supõe um deslocamento espaçotemporal no qual se está ao mesmo tempo dentro e fora da linguagem.

\section{Considerações finais (ou notas porvir)}

Os lugares onde os escritores escrevem não guardam qualquer padrão integralmente compartilhável entre eles, não apenas em relação a Autran Dourado, Ana Miranda, Régis Bonvicino, Bernardo Carvalho e Adélia Prado, mas a todos que estão no trabalho de Chiodetto. Seus ritos, místicas, modos, manias, (des)organizações e hábitos são contaminados pela diferença babélica que se unifica heterogeneamente em suas produções literárias, fotografias e biografemas. Não há nada natural em suas imagens e narrativas de si: são poses, estratagemas, máquinas do artifício que, não por isso, são mentiras absolutas, mas verdades temporárias, poeticamente fingidas.

Em Cascas, Didi-Huberman provoca o leitor a pensar os limites críticos das noções de aparência e essência, debate filosófico dos mais clássicos, para além do mero binarismo opositor, nos convocando a refletir acerca da supervalorização de uma possível substância no interior das coisas e do "valor" alocado no que elas escondem. Uma postura de oposição cintila: "[...] a substância decretada para além das superfícies não passa de um embuste metafísico" (DIDI-HUBERMAN, 2017, p. 131). A superfície é o que cai. Percebendo isso nos daremos conta de que as cascas (as aparências) procedem diretamente das coisas, inscrevendo-se em uma afluência dobradiça que tanto procede quanto se separa delas.

A alegoria da casca esboça um continuum singular que toca a fotografia e o biografema. Uma foto é um artefato, "lascas fortuitas do mundo" que, tirando partido da magia da realidade e do prestígio da arte, lembram "nuvens de fantasia e pílulas de informação" (SONTAG, 2004, p. 84). Os biografemas, por sua vez, não estão na contramão da biografia, mas ceifam o verticalismo e a cronologia historicizantes e instauram uma terceira margem de sentidos sobre o vivido/ficcionalizado. As fotografias nos dão acesso a uma consciência fragmentária do real e os biografemas fabricam um palimpsesto biográfico que atualiza e diversifica a consciência histórica, imprimindo-lhe a contingência e a incerteza do acontecimento, do esquecimento, da reminiscência, do dissenso e da micro-história.

À medida que a casca não é menos verdadeira que o tronco, acrescento que, tampouco, a luz do pirilampo é menor porque descontínua; a imagem revelada pelo estilhaço menos significante que a do espelho inteiro; ou um retalho (ou uma tira, como se diz no Nordeste do Brasil) é menos útil que uma peça de tecido. Essas metáforas recorrem a formas e vidas cotidianas presumivelmente banais, que conservam em seus limiares de significação a irregularidade, o terreno acidentado e imperfeito. As breves entrenotas aqui dispostas são motivadas pela intenção de construir uma escrita sobre fotos e palavras como um texto de citações, em analogia direta ao que propõe Susan Sontag no ensaio Objetos de melancolia: uma foto pode ser descrita como uma citação. O lugar do escritor, de Eder Chiodetto, entrecruzamento de imagens e palavras, é um convite à leitura de impurezas e efemeridades que transitam com originalidade e beleza entre a insígnia da morte assinalada pela fotografia e o signo da vida reinventado narrativamente nos biografemas.

\section{Referências}

BARTHES, Roland. A câmera clara. 2. ed. Tradução de Júlio Castañon Guimarães. Rio de Janeiro: Nova Fronteira, 2015.

BARTHES, Roland. Sade, Fourier e Loyola. São Paulo: Martins Fontes, 2005.

BAUDELAIRE, Charles. A modernidade de Baudelaire. Apresentação de Teixeira Coelho. Rio de Janeiro: Paz e Terra, 1988.

BENJAMIN, Walter. Paris do segundo império. In: BENJAMIN, Walter. Charles Baudelaire: um lírico no auge do capitalismo. São Paulo: Brasiliense, 1989.

BERNARDO, Gustavo. O livro da metaficção. Rio de Janeiro: Tinta Negra, 2010. 
CHIODETTO, Eder. Curadoria em fotografia: da pesquisa à exposição. São Paulo: Prata Design, 2013.

CHIODETTO, Eder. Geração oo: a nova fotografia brasileira. São Paulo: Edições SESC, 2013.

CHIODETTO, Eder. O lugar do escritor. São Paulo: Cosac \& Naify, 2002.

DELEUZE, Gilles; GUATTARI, Felix. O que é a filosofia? Rio de Janeiro: Editora 34, 1992.

DELEUZE, Gilles; GUATTARI, Félix. Mil Platôs. Rio de Janeiro: Editora 34, 1995. v. 1.

DERRIDA, Jacques. O olho da universidade. São Paulo: Estação Liberdade, 1999.

DIDI-HUBERMAN, Georges. Cascas. São Paulo: Editora 34, 2017.

ELIAS, Norbert. A sociedade dos indivíduos. Rio de Janeiro: Jorge Zahar, 1994.

FLUSSER, Vilém. Texto/imagem enquanto dinâmica do Ocidente. Cadernos Rioarte, Rio de Janeiro, v. II, n. 5, p. 64-68, 1986. Manuscrito Arquivo Flusser, Berlim.

FOUCAULT, Michel. Nietzsche: a genealogia e a história. In: FOUCAULT, Michel. Microfísica do poder. 6. ed. Rio de Janeiro: Edições Graal, 1986.

LÉVI-STRAUSS, Claude. O pensamento selvagem. Campinas: Papirus, 1990.

MACHADO, António. Poesías completas. Buenos Aires: Losada, 1944.

PESSOA, Fernando. Obra poética. 3. ed. Rio de Janeiro: Nova Aguilar, 2005.

RANCIÈRE, Jacques. A partilha do sensível: estética e política. São Paulo: Editora 34, 2009.

ROSA, João Guimarães. Grande sertão: veredas. Rio de Janeiro: José Olympio, 1979.

SONTAG, Susan. Sobre fotografia. São Paulo: Companhia das Letras, 2004. 